\title{
A Critical Discourse Analysis of Political News Reports
}

\author{
Meiling Zhang \\ Canvard College, Beijing Technology and Business University, China
}

\begin{abstract}
News reports are considered as the reflection of world reality. People all over the world watch news reports to get the information they need. Languages in the news reports are naturally thought to be neutral and unbiased. This paper will conduct a critical analysis of the political news reports on Iraq war by American media. Fairclough's three dimensional frameworks and Halliday's functional grammar will be employed to do the research, in which linguistic features, news production and social contexts are explored. However, the result of the analysis in this paper tells us that, against the traditional views, languages in the news report are never biased-free. They are branded by the social values and different ideology. As a result, it is advised to increase the cultural awareness for the new readers.
\end{abstract}

Index Terms - political news discourse, Iraq war, three-dimensional framework, functional grammar

\section{Discourse Analysis AND Theoretical Framework of This PAPER}

\section{A. Discourse Analysis}

There are many definitions of discourse analysis in literature. Discourse is defined as connected texts as opposed to isolated sentences. Thus discourse analysis refers to a study of large linguistic units, such as conversational exchanges or written texts. Discourse analysis, in this sense is the analysis of language in use (Brown and Yule, 1983). However, in a wider sense, the task of the discourse analysts is not only to describe the textural features of the texts but also to deal with the relationship between discourse and reality. A comprehensive process of discourse analysis should include not only texts, but the social and institutional contexts in which they are produced. In this paper, we hold the critical view. That is a 'process' view which regards discourse as a social practice, a whole process of production, distribution and consumption and discourse analysis as dynamic process.

\section{B. Theoretical Framework}

The sample analysis in this paper will be based on Fairclough's three-dimensional framework and the linguistic instrument it bases on: Halliday's functional grammar.

Fairclough sees language and discourse as social practice. He suggests that critical analysts should commit not just to analyzing the texts, nor just to analyzing processes of production and interpretation, but to analyzing the relationship between texts, processes and their social conditions, both the immediate conditions of the situational context and the more remote conditions of institutional and social structures. (Fairclough, 1989) Fairclough divides discourse into three dimensions: texts, interactions and contexts. As for news discourse, texts refer to the news reports we read in newspapers---the words-on-page. Interactions involve the production and consumption of news reports and contexts refer to the background of the events reported, the situational and social reality. Corresponding to the three dimensions of discourse, Fairclough proposes a stepwise procedure in conducting critical discourse analysis:

Description is the stage which is concerned with formal properties of the text---properties of vocabulary, grammar, textual structures, etc. In conducting a critical study of news discourse, this stage will deal with the linguistic features of the news reports drawing upon the analytical instruments in functional grammar.

Interpretation is concerned with the relationship between text and interaction. In news discourse, the interpretation stage will deal with the intertextual phenomena of news production from the perspective of news sources, speech reporting, etc.

Explanation is concerned with the relationship between interaction and the social context---with the focus on social determination of the processes of production and interpretation, and their social effects. As for news discourse, the hidden ideology as well as its relationship with language use is unmasked finally at this stage.

\section{SAMPLE ANALYSIS}

\section{A. Overview}

Following the three-dimensional framework and the analytical tools of functional grammar elaborated above, a study of political news discourse will be conducted to specific news items in this section. The news is collected from the most influential media in the United States of America, to be specific, New York Times. The news covers stories on the war in Iraq. 


\section{B. Linguistic Features of the News Report}

\section{Transitivity}

Transitivity is of ideological significance. The following figure gives us a clear idea of the frequency of each process type that is employed in the sample news report.

FIG.1

DISTRIBUTION OF PROCESS TYPES IN THE SAMPLE NEWS REPORT

\begin{tabular}{|l|l|l|l|}
\hline Material Process & Relational Process & Verbal Process & Mental Process \\
\hline $67 \%$ & $16 \%$ & $11 \%$ & $2 \%$ \\
\hline
\end{tabular}

From the above figure, we can find that material processes occupy the most prominent position in this news report. According to Halliday, material processes are processes of 'doing'. They express the notion that some entity 'does' something---which may be done 'to' some other entity. Since new discourse concentrate on reporting what happened or is happening, the language in news discourse thus inevitably involve telling about a series of actions. And the reporting on any event can not be a vacuum of material processes.

E.g. 'In Baghadad, Free of Hussein, a Day of Mayhem', is news story on the situation in Baghadad after the overturn of Saddam's reign on April 9, 2003. 67\% of the processes are the material. What should be noted is that, the agent positions of these material processes are sharply grouped into two sides: one stands for the American troops or Bush administration and another is the Iraqi city or the citizens. And in the case of the American side as the agent, the Iraqi side often takes the role of goal or patient, and vice verse. For example:

A. American troops cleared wide swaths of the capital of Iraqi force today

B. The State Department... would send 26 police and judicial officers to Iraq...

C. But the city was the scene of frenzied rounds of looting, with mobs setting fire to government ministries and moving for the first to ransack private homes rather than merely the symbols of Mr.Hussein's power.

D. The mayhem clearly put pressure on American military commanders supervising the occupation...

The contrast provides to the news reader with a vivid picture of the two sides: the victory of the American forces and the collapse of the Iraq. The American side takes the role of the agent, it is doing something: it is doing something as the liberator of Iraq and the people in Iraq. At the same time, the Iraqi side is also doing something: it is being destroyed, suffering from collapsing and looting, it is described as a patient waiting for medical treatment by some skillful doctor. And the American side naturally claims to be the 'doctor'. From the above analysis, material processes contribute to the construct of the roles of the two sides. It is reasonable to say that this news report stresses the post-war Iraq and the miserable picture of the attacks. The American side looks like the liberator of Iraqi people. They suffer from the attacks of Saddam's forces and still go on fighting for the peace and safety of Iraq. On the contrary, Saddam Hussein looks like a tyrant who oppressed people in Iraq and is hated by the people for years. In this way, the media contributes to get the sympathy of the masses in America as well as the other countries and gain their support to the war.

To sum up, transitivity means choice. Which types of processes are employed depend on the assumptions and beliefs of the reporter. Language, in this sense can contribute to construct as well as reflect reality.

\section{Transformation}

Nominalization is one type of transformations. Nominalization and the use of nouns for actions are endemic in political news reports. Here are two examples from the sample news report:

(1) “...the city's hospital's today received more casualties from rioting and looting than from the war."

(2) The mayhem clearly put pressure on American military commanders supervising the occupation to begin changing a war-fighting operation into one that keeps order and peace.

In the above examples, the nominal forms are derived from verbs or adjectives. Apparently, much information goes unexpressed in a nominal form compared with a full clause. At the same time, nominalization helps to weaken the sense of action and impersonalize the processes. Thus the media try to look as unbiased as possible.

\section{Classification}

Classification refers to the naming and representing of people and events. It is mainly realized through the choice of vocabulary. Different means of naming reflect the reporter's attitude towards the person being referred to and inevitably produce different impression on the readers.

The repeatedly use of the tow words 'we' and 'he' shows the opposition: the intimacy of the American government with its people and the distance or hatred between the Americans, the 'people' and Saddam Hussein. Once more, the media impose an impression on the readers that Saddam Hussein is the enemy. Another means of classification is realized by the adjectives. When describing the 'caught' of Saddam Hussein, unfavorable adjectives are employed. However, the image of the American forces looks like very favorable described by such words as 'friendly' and 'liberator'.

To sum up, language is never neutral. It represents a world as perceived by the ideological needs of certain groups of people and constructs a 'created' reality. In the news report we analyze, the media create quite different images for Saddam Hussein and the American forces by choice of vocabulary. A sharp contrast is made between the two sides in the war.

\section{Modality}


Modality is a tool of expressing the 'attitude' or 'comment' of the speaker or writer. It is through modality that the news reports express their recognition with the statements of others or present their comments on the event or the people involved. Thus, modality works as a bridge between the media and the historical backgrounds. In the sample report, high affinity is entrusted while stating the American's determination and confidence in arresting Saddam Hussein and fighting the war. This can be illustrated by the frequent use of 'would' in the report. However, when describing the post-war situation in Iraq, the reporter employs the low affinity modality. For example, 'appear' and 'seem' are frequently used. In doing so, the reporter imposes on readers an impression that Iraq is a disaster and the United States is the very 'liberator' who will save Iraqi people from the disturb.

\section{Interpretation of the Sample News}

At this stage, the news will be regarded as an animate process. A news reporter has a lot of choices to convey a particular position or attitude towards the event being reported. He may decide whose speech is to be quoted. He may quote the speech directly or indirectly. He may choose which mode of speech reporting is employed and whether the news sources are identified specifically or not. Any choice can transmit certain ideological meanings of the reporter and thus influence the readers intentionally unintentionally. The sample news highlights the voices of the American side and creates a positive image for Bush administration and a negative image of Saddam Hussein. This is a result and a reflection of the ideology.

\section{Explanation of the Sample News Report}

Explanation is the last stage to analyze this news report. Through the above analysis, we know that news reporting is not self-sufficient. It rests on the bearing with the political and governmental institutions. As for this news, it is shaped by the social structures of its nation and meanwhile reproduces and reinforces the social structures. We can see that the production of this political news discourse rests on the social and cultural settings and it is the mirror of the social structures. The political news discourse is a bridge between the masses and the authority.

\section{CONCLUSION}

This news report is analyzed by Fairclough's three-dimension framework and Halliday's functional grammar. This study ranges from the micro scope---linguistic features, to the macro scope---social and cultural settings. The reporter employs various linguistic tools to set up quite different images for the American side and the Iraqi side. Reading through the news report, a defeated Saddam Hussein and a righteous troop of the United States are imposed on mind. The reports help to criticize Saddam, win support and finally justify the war. It should be pointed out that the reporter may achieve these effects unintentionally. It is the hidden ideology that guides the reporter to write for the United States. His language use inevitably reflects his distinctive attitudes towards the two sides.

The three-stage analysis reveals that language and ideology is mutually determined. The language in news discourse is by no means neutral. The American media report the war in Iraq for the interests of their own nation. The analysis of this news report shows us that critical analysis is of great significance in assisting news readers not only to achieve a better understanding of what they are reading but to learn more about the social and cultural background. Critical analysis will help news readers to increase critical sensitivity and awareness.

\section{APPENDIX. (SAMPLE NEWS REPORT FROM NEW YORK TIMES)}

In Baghdad, Free of Hussein, a Day of Mayhem

By DEXTER FILKINS

New York Times

AGHDAD, April 11 American troops cleared wide swaths of the capital of Iraqi forces today, but seemed powerless before a fresh wave of looting and mayhem that flowed in to take their place.

A week after American troops entered the city for the first time, large unbroken stretches of Baghdad's urban center, on both sides of the Tigris River, seemed free of the bands of Saddam Hussein loyalists who have been harassing American forces for the last seven days.

But the city was the scene of frenzied rounds of looting, with mobs setting fire to government ministries and moving for the first to ransack private homes rather than merely the symbols of Mr.Hussein's power.

With virtually every government ministry here in flames, the city of Badhdad and indeed the entire country is now operating essentially without a government, with no services or police protection.

The Bush administration appeared to have little prepared in the way of a quick response. Defense Secretary Donald $\mathrm{H}$. Rumsfeld said in Washington "You cannot do everything instantaneously." He added: "It's untidy. And freedom's untidy. And free people are free to make mistake and commit crimes."

The State Department said it would send 26 police and judicial officers to Iraq as the advance team for what might eventually be a contingent of more than 1,150 people to help restore law and order. They will be part of a group led by Lt.Gen. Jay Garner, the retired general chosen by the Bush administration to run the initial Iraqi civil administration under American occupation.

In Baghdad, military officials said American troops would try to ensure that religious centers remained open and that 
public services functioned.

American officers said they had begun enlisting local Iraqi officials to help rebuild police forces as fast as possible. But with hospitals being ransacked and many people still wary of going onto the streets, any resumption of normal life and service appeared remote.

Whole city blocks were descended upon by greedy mobs today, with some people backing trucks into offices and department stores to fill them with stolen merchandise.

Gun battles broke out between packs of looters and defenders of their property, and the city's hospital's today received more casualties from rioting and looting than from the war.

Most of the city was still without electricity or fresh water, and with almost every shop still shuttered, Baghdad residents have begun to worry that shortages are reaching a critical point.

The mayhem clearly put pressure on American military commanders supervising the occupation to begin changing a war-fighting operation into one that keeps order and peace. But the fact is the war is not over. Recent days have been marked by suicide bombings against American troops, by the continuing manhunt for senior members of the Mr.Hussein's leadership, and by preparations for a military strike against Mr.Hussein's hometown of Tikrit, about 110 miles north of here.

The military's first priority to crush Mr.Hussein's government appears to be proceeding apace, and the good will so much in evidence here over the last several days has not dissipated yet, although it is by no means uniform.

But the widespread anarchy that followed the first moments of liberty here this week has become a central problem for American soldiers and marines, who constitute the only visible presence of any form of order.

The mayhem gave rise today to signs of widespread Iraqi anger over the direction of the American enterprise here.

But there were also distinct signs of progress. Large tracts of the city appeared to be clear of both civil disturbance and enemy activity. A 10-mile-long strip of the urban core, running along the Tigris River, appeared calm today for the first time since Mr. Hussein's government fell.

The five main bridges linking the two sides of the city over the Tigris were opened today, allowing traffic to flow freely. In some neighborhoods, American tanks that had parked on the street corners have simply moved out, so certain are the soldiers that enemy is gone.

Indeed, the Americans felt so secure in some areas that they sent their troops for some secondary, if emotionally satisfying, pursuits.

At the Rashid Hotel, where many foreign journalists visiting Mr.Hussein's Iraq were required to stay, American troops were sent to break up a tile mosaic of the first President Bush on the floor of the lobby. Until the mosaic was destroyed today, the likeness of Mr.Bush was stepped on dozens of times a day.

There were also glimpses that the banishment of pro-Hussein forces from parts of the city was being sustained by Iraqis themselves.

In Arasat, an upscale area of boutiques and restaurants, pedestrians were seen shouting at fedayeen fighters who had rumbled into the area on a battered old bus. Some of the residents tried to pull the armed men off the bus, and others tried to force the bus to turn into the line of fire of an M-1 Abrams tank parked up the road. The busload of fighters dashed down a side street, fleeing the angry Iraqis.

"These people couldn't be more friendly," said Lt.John R. Colombero, a marine on patrol in a downtown neighborhood today. Asked for evidence, he flourished a freshly picked wildflower that had been stuck into the front of his Kevlar vest by an effusive local.

"See that?" he asked.

In fact, when Lieutenant Colombero's company blew up an Iraqi ammunition cache, rattling homes for blocks, the neighbors came out into the street to complain. But the very quaintness of the complaint and excessive noise in a residential area seemed a measure of how far the American forces had come.

In neighborhoods across the city, however, the order and peace disintegrated as the last of Mr. Hussein's forces were swept away.

Two more government agencies, the Information Ministry and the Higher Education Ministry, were set afire today by mobs. The Mansur Hotel, a downtown landmark, was also torched. Before the Americans arrived, the Rashid Hotel was ransacked by looters, who virtually emptied the huge structure of its every chair, lamp and light bulb.

Some of the most frenzied looting of the day unfolded at the Sajida Palace, a grandiose structure even by the gaudy standards of the Iraqi president. There, a huge crowd of looters carted out nearly every piece of furniture and adornment that could be lifted or torn from the walls. Whole families worked together, carrying out gilded $18^{\text {th }}$ century-style chairs, wall friezes, beds and tableware.

The looters included not only the usual throng from the city's poorer precincts, but the professional class as well.

"I don't feel any guilt at all," said a pharmacist, who came with her husband, an obstetrician, and two children, to help themselves to brocade sofas and heaps of Wedgwood. "I paid for these a thousand times."

Mr. Hussein's palace, completed in 1999, was constructed on the site of the palace of King Faisal, Iraq's first monarch, who met a violent end when he was overthrown in 1958. Then, the building was called "The Palace of the End," and as the measure of Mr. Hussein's excesses were carted into the streets, that title seemed to have a special irony today. 
The looters surged through the city's streets. Having hit every other hospital on the block, a mob came to AI Wasety Hospital, and began banging on the door. One of the doctors, a soft-spoken and overworked man named Yasir mousawi, pulled a Kalashnikov rifle from a supply closet and fired a single shot into the air. The crowd dispersed.

For the most part, the Americans seemed incapable of controlling the crowds. On the streets where American soldiers worked, the scene was invariably quiet. Faced with a potential calamity, they acted with dispatch. When a gang of looters began to cart away rocket-propelled grenades from an armory at the Ministry of Planning today, American soldiers moved quickly to disperse the crowd. But there were far too few American soldiers moved quickly to disperse the crowd. But there were far too few American soldiers to the make a difference in most neighborhoods.

That failure began to provoke anger among many middle-class Iraqis who did not take part in the looting but who feel defenseless against it. At the Ani Mosque today, a group of men confronted an American reporter, angrily denouncing the Bush administration for destroying the city's public administration and doing little to replace it.

"We have no security here," said Hamid Adel Mustaf, the imam. "Listen to the gunfire outside. We cannot even pray in our mosque without hearing the gunfire in the streets."

Another man, Nabil Abed, said, "This is what America has brought us: looting and destruction."

There was evidence today that the American forces were preparing to move more quickly away from fighting and toward occupation and administration. Maj. Paul Konopka, a civil affairs official with the Marines, said he planned to meet soon with religious leaders in the city about problems of electricity, looting and the maintenance of civil order.

Major Konopka said much of the looting was taking place was carried out by people "expressing their dislike of the old regime," but he suggested that the emotion had been taken too far. "There is a fine line between being comfortable with freedom, and chaos," he said.

\section{REFERENCES}

[1] Brown, G \& Yule G (1983). Discourse Analysis. London: Cambridge University Press

[2] Cook, G. (1989). Discourse. Oxford: Oxford University Press.

[3] Coulthard, Malcolm. (1977). An Introduction to Discourse Analysis. London: Longman.

[4] Fairclough, N. (1989). Language and Power. London: Routledge.

[5] Gee, J. P. (1999). An Introduction to Discourse Analysis: Theory and Method. London: Routledge.

[6] M. A. K. Halliday. (1985). An Introduction to Functional Grammar. London: Edward Arnold.

Meiling Zhang was born in Jiangsu, China in 1981. She received her Master of Arts degree in foreign language studies from University of International Business and Economics, China in 2006.

She is currently a lecturer in Canvard College, Beijing Technology and Business University. Her research interests include college English teaching and business English. 